\title{
The Mystic Path of Shaikh Bahauddin Zakariya
}

Dr. R. Subramony

Associate Professor and Head of the Department

Department of English (Autonomous)

Madurai, Tamil Nadu, India

raaja.dhruv@gmail.com

\begin{abstract}
Shaikh Bahauddin Zakariya (1182-1262) laid the foundation of the Suhrawardi order in Multan, which played a significant role in the socio cultural history of north-western India. His ancestors had migrated from Mecca and settled in Multan. His father Shaikh Wajihuddin was married to the daughter of Maulana Husamuddin Tirmizi, who had migrated to Punjab in the wake of the Mongol invasions. Bahauddin Zakariya was born at Kot Karor, a village near Multan. While still a young boy, he memorized the Quran and learnt to recite it in seven styles of recitation. During a long stay in the famous centres of education - Khurasan, Bukhara, Madina and Palestine- he studied the traditional subjects.
\end{abstract}

Keywords- Shaikh Bahauddin Zakariya, Suhrawardis, Shaikh Nizamuddin Auliya

Humaira Arif Dasti states, "Shaikh Bahauddin Zakariya (1182-1262) laid the foundation of the Suhrawardi order in Multan, which played a significant role in the sociocultural history of 
north-western India. His ancestors had migrated from Mecca and settled in Multan. His father Shaikh Wajihuddin was married to the daughter of Maulana Husamuddin Tirmizi, who had migrated to Punjab in the wake of the Mongol invasions. Bahauddin Zakariya was born at Kot Karor, a village near Multan. While still a young boy, he memorized the Quran and learnt to recite it in seven styles of recitation. During a long stay in the famous centres of education Khurasan, Bukhara, Madina and Palestine- he studied the traditional subjects." (80) For several years, he performed religious devotions at the mausoleum of Prophet Muhammad in Madina and learnt the prophetic traditions (hadis) from a distinguished scholar of the discipline. During a visit to Baghdad, he was initiated into the Suhrawardi order by Shaikh Shihabuddin Suhrawardi. According to one account, he was made a spiritual successor (khalifa) after tutelage of just seventeen days. His mentor declared that senior aspirants could not achieve their aims as they brought green wood which would not catch fire, while Bahaduddin Zakariya brought dry wood which began to burn at a single breath. On returning to Multan, Bahauddin Zakariya planted the seeds of the Suhrawardi order in spite of the opposition of some religious men of the city. The Shaikh's multifarious activities- mystical, educational and literary-were undertaken precisely at the time when Shaikh Farid Gani-i-Shakar was engaged in organizing the Chishti order from the neighboring town of Pakpattan. Bahauddin Zakariya has been criticized by several contemporaries and modern writers for his involvement in politics and accumulation of wealth.

\section{Conditions in the Multan Region}

During the late twelfth and early thirteenth century, the political condition in Punjab was characterized by the decline of the Ghaznavid rule, establishment of the decline of the Ghaznavid rule, establishment of the Delhi sultanate, internal conflict in the new ruling class and recurrent 
Mongol invasions. The emergence and expansion of the Saljuq empire threatened the existence of the Ghaznavids whose sway was reduced to parts of the southern and eastern Afghanistan and Punjab. As the Saljuqs began to lose ground to the Ghuzz Turks, the Ghurid princes (who had been the vassals of the Saljuqs) availed themselves of the opportunity to build their own political power. In this rise of the Ghurids, a notable role was played by Izzuddin Husain, Bahauddin Saj and Alauddin Jahansoz. A tripartite division of the Ghurid empire placed Ghazni in the hands of Sultan Muizuddin (r. 1173-1206 ) who went on to lay the foundation of the Delhi sultanate. The series of is military expeditions, which were spread over three decades, brought about a fundamental change in the history of Punjab up to Delhi and expended the frontiers of the new kingdom to Ajmer, Gwalior and Benares, paving the way for quick success in Bihar and Bengal. The sudden and unexpected death of Sultan Muizzuddin in 1206 marked the beginning of a power struggle in Punjab among his Turkish slave officers -Wutbuddin Aibak in Delhi and Lahore, Nasiruddin Qubacha in Multn and Uch and Tajuddin Yalduz in Ghazni. The place of Aibak was taken after his death (1210) by Shamsuddin IItutmish. But the power struggle continued as before. After a series of military operations, IItutmish defeated his rivals (Yalduz and Qubacha) and, by 1220, established a firm control over Punjab and placed his son Nasiruddin Mahmud in charge of Lahore.(Sijzi, 105)

During this period, Multan became the focus of attention owing to the rebellious activities of the successive officers associated with it- Kabir Khan Ayaz, Izzuddin Balban Kishlu Khan and Sher Khan. During the reigns of IItutmish and his successor Ruknuddin Firuz Shah, Ayaz had served as the governor of Multan and Sunam respectively. He joined the revolt raised by the governors of Lahore and Hansi. He managed to extract the administration of Multan from Sultan Raziya, but began to rule independently over Muyltan, Uch and Sind. Ayaz and his son 
Tajuddin Abu Bakr defended Multan, Uch and Sind. Ayaz and his son Tajudin Abu Ayaz defended Multan against the Qarlugh expansion. During the reign of Nasiruddin Mahamur (r. 1246-1266), Kishlu Khan was given the charge of Multan and Uch. When Saifuddin Hasan Qarlugh besieged Multan (1219), Kishlu Khan surrendered the fort and retreated to Uch. Sher Khan, who was holding the charge of Lahore and Bathinda, ousted the Qarlugh agent from Multan. Not only did he assume control of Multan, but also established his sway over Uch. Thus began a conflict between the two officers, Kishlu Khan and Sher Kahn, for the possession on Multan. The Delhi sultan marched into Punjab, expelled Sher Khan and restored to Kishlu Khan the charge of Multan and Uch. Alienated from Delhi Sultanate, Sher Khan went to Turkistan and sought alylum at the court of the Mongol chief Mangu Khan. Kishlu Khan, feeling uneasy at the rise of Ulgh Khan at Delhi, sent his son to the court of the Mongol ruler Halaku. He also joined hands with the rebel Qutlugh Khan and participated in an abortive attempt to dislodge the Sultan. Subsequently, he fled to Khurasan and appeared at the court of Halaku. He secured the promise of support in return for accepting a Mongol resident (shahna) in his territories. From now onwards (1295), he began to rule independently in Multan and Uch, whichcame under the protection of the Mongols. (Humaira Arif Dasti, 83).

The city and hinterland of Multan commanded immense strategic and economic importance. The region formed and irregular triangle, being enclosed by the Chenab and Satluj. The streams of the Ravi and Beas separately traversed through the area before merging with the Chenab and Satluj just above Uch. The land near the confluence of the rivers was regularly flooded during the summer months. The soil was entirely alluvial. Wheat and cotton were the major crops, while the date palm was also cultivated. The rainfall was extremely scanty, the average varying from 4 to 7 inches. From the point of view human settlement, Multan appears to 
have been better placed than the Sind Sagar Doab on its northwest and the Thar Desert on its south. The city of Multan emerged as a significant entrepot, because it was situated at the crossroads of the overland and riverine routed the connected India with the lands on the west, Iran and Arabian Sea. It was suitably connected with several urban centres in the region viz. Lahore, Dipapur, Pakpattan, Tulamba, Uch and Bhakkar. It appears that the transcontinental route connecting Delhi with Qandahar, which passed through Multan, overtook others in Significance. Multanis, who played a prominent role in ling distance trade, dealt in horses, slaves and indigo. Since Ziauddin Barani, refers to Multanis in conjunction with Sahs, it indicates that Multanis were Hindus who were engaged in usury and commerce. We must hasten to point out that some Multanis were Muslims also. We are aware that Hamiduddin, who appointed as the Chief judge by Aladdin Khalji, was known as a great merchant (malikut tujjar) and had been engaged in taking interest since the time of his grandfather and father. This Sultan had assigned a special role to the Multanis in his scheme of price regulation. He appointed them as officers in the market of non-agricultural goods (sarai adl) in Dehi and gave them an advance of 21 Lac tankas, so that they were able to bring superior quality textiles to the capital for sale. The prosperity of the Multanis was also based on the interest which they earned from loans advanced to the nobles of the Delhi sultanate. The Multanis had not risen to sudden prominence towards the end of the thirteenth century and that they had been playing a multifarious role in the internal and external trade as well as the polity of the Delhi sultanate for a long time.

(Khaliq Ahmad Nizami, Religion and Politics in India during the Thirteenth Century, 238) 


\section{Mystical Beliefs and Practices}

In his mystical ideology, Shaikh Bahauddin Zakariya faithfully adhered to the path of his spiritual preceptor Shaikh Shihabuddin Suhrawardi who, in turn, had imbibed the teachings of Shaikh Junaid Baghdadi. The last named stood against free thinking and deviations from the canonical law and, therefore, advocated that the mystical path (tariqat) was subordinate to the religious law (shariat) under all circumstances. This position was opposed to the extremely rebellious mystics who treated shariat and tariqat as mutually exclusive and believed that the former acted as a guide in the everyday life of the individual and could not provide guidance in the higher spiritual matters. Shaikh Bahauddin Zakariya laid utmost emphasis on performing obligatory religious duties, because it served as the basis of all spiritual progress. He attached secondary importance to recollection of God (zikr), supererogatory prayers and sufi discipline. For him, mysticism (tariqat) was more than a method to learn spiritual purity. It meant that every thought and action was related to the larger purpose of returning to the Divine. It also meant that the seekers were responsible for controlling themselves at every moment and every place. The Shaikh's emphasis on the internal and external make-up of the seeker required a strict observance of the Quran, hadis, shariat and mystical practices, besides subordination to political authority and social etiquette. (Rizvi, 193).

According to the Shaikh's advice, as recorded in the Majma-ul-Akhbar, a seeker was required to remember God with love and sincerity. The latter achieved this state when, suring prayer and recollection of God was expelled from the heart. His behaviour was guided by only those thoughts and actions which were essential. Only then God gave him the wisdom to undertake good actions. In his advice to a disciple Rehman, the Shaikh required him to engage in recollection of God (zikr) at all times, because by doing so he could reach his ultimate 
destination. Love was like a fire that destroyed every kind of dirt and filth. When his love became steadfast, then he became attached to zikr-i- mushahida. It was on the basis of this particular kind of zikr that God promised success and prosperity, in accordance with the Quranic verse. "Undertake excessive zikr, so that you become successful." (Humaira Arif Dasti, 88). It appears that Shaikh Bahauddin Zakariya provided instructions to his disciples by writing letters to them. He had high expectations from his disciples, particularly regarding a single minded commitment to God. In a letter to one of his disciples, he narrated an anecdote which must have been learnt from his spiritual teacher Shaikh Shihabuddin Suhrawardi. We are told that Shaikh Shihabuddin Suhrawardi and his mentor Abu Najib Abdul Qahir went on a pilgrimage to Mecca. We are told that Shaikh Shihabuddin Suhrawardi and his mentor Abu Najib Abdul Qahir went on a pilgrimage to Mecca. When they entered the Kaaba, Abu Najib Abdul Qahir reached a higher plane of spiritual consciousness (alam-i- asrar) and became so immersed in this state that he did not pay any attention to the arrival of hazrat Khizar, who ultimately left the place. When he regained his worldly consciousness, his disciple gathered courage and asked the reason for not paying attention to a prophet who had come to see him. Abu Najib Abdul Qahir became red with anger and said." Alas, you do not know the reason. If this moment had been wasted, it would not have come again and we would have felt ashamed till the day of judgement. "While this conversation was in progress, Hazrat Khizar arrived and was met by Abu Najib Abdul Qahir with all marks of respect. The moral of the story is that the seeker was required to defend his time as something exceedingly precious. He should avoid meeting people and make this action impermissible for himself. He should realize that social intercourse resulted in wastage of time. He should acquire loving intimacy from remembering God (zikr). If he failed to do this, he would not feel the sweet fragrance of God's love. The Shaikh wrote to 
another disciple that eating less led to protection of the soul and offering greetings to the Prophet led to the consolidation of religion. Approving the mystical method of the Shaikh Nizamuddin Auliya stated that he modeled his life on the Quranic injunction "Eat of what is pure and act righteously."

Maracles have been attributed to most sufis. The hagiographical literature was so replete with the accounts of miracles that they had become an indispensable part of such writings. The sufis themselves had a different attitude to the performance of miracles. In the case, Shaikh Bahauddin Zakariya, we have at least one reference which shows his aversion to the act. According to an incident recorded in the mystical discourses of Syed Jalaluddin Bukhari Makhdum -i- Jahaniyan, Jami-ul-Ullum, one day Shaikh Bahauddin Zakariya was taking rest, while his disciple Ali Khokhar Darvesh was pulling the fan to freshen the air of the room. When the disciple left for offering his prayer, he beckoned the fan to keep moving. When the disciple left for offering his prayer, he beckoned the fan to keep moving. When the Shaikh woke up, he was surprised to find that the disciple was missing, while the fan was moving. The Shaikh was outraged at this display of miraculous power by his disciple. Giving vent to his anger, the Shaikh cursed the disciple with perpetual hunger, so that the more he ate the hungrier he felt. It was only the kind intervention of Shaikh Jalal Tabrezi, which miraculously cured the poor disciple of his misery. Offering a different versions of the episode, Syed Muhammad Gesudaraz narrates that Shaikh Bahauddin Zakariya kicked Ali Khokhar Darvesh (reason not mentioned) as a result of which the latter's taste buds and digestive organs were so activated that he ate and indulged himself endlessly and went about scolding his own mentor. (Humaira Arif Dasti, 90).

It is true that Shaikh Bahauddin Zakariya did not show interest in the philosophical aspects of mysticism, but confined himself to the practical aspects and spiritual purity. This view 
is confirmed by a book in Arabic al-Aurad, the authorship of which has been attributed to the Shaikh. A commentary of this work was prepared by Maulana Ali bin Ahmad Ghurim, who was a disciple of Ruknuddin Abul Fateh, the grandson of the Shaikh. This work elucidates some basic religious doctrines and lays down instructions for the seeker in simple and direct manner. It also comprises prayers and Zikr formulae, which have been compiled in the style of early traditionsits (muhadissin), who provided legal solutions that were applicable to social problems. Owing to the inspiration and encouragement of the Shaikh, a number of people belonging to his mystical circle devote their energies to literary production. The first person in this category was Fakhruddin Iraqi. He was a nephew of Shaikh Shihabauddin Suhrawardi and had studied Fasus-ul-Hikam under the tutelage of Sadruddin Qunvi, who was a disciple of Ibn-i-Arabi. Iraqi is said to have fallen in love with a certain youth and followed him and a group of dervishes to India. On reaching Multan, he was so impressed by the magnetic personality of Shaikh Bahauddin Zakariya that he stayed in the city for the next twenty five years and composed laudatory verses (qasidahs) in his praise. According to one account, Iraqi locked himself in a cell (acting on the directions of the Shaikh) for ten days and did not permit anyone to enter. On the eleventh Day, he was overcome by emotion and sang aloud while weeping:

The wine wherewith the cup they first filled high

Was borrowed from the saqi's languorous eye.

Since such an act of singing was not permitted within the precincts of the Suhrawardi hospice, the inmates lodged a complaint with Shaikh Bahauddin Zakariya who, instead of issuing any reprimand, exclaimed that the recitation of poetry was forbidden for the complainants, but not for Iraqi. After a few days, it was learnt that the poems of Iraqi were being sung in the bazaar and taverns to the accompaniment of musical instruments. When the matter was reported to the 
Shaikh, he went to Iraqi's cell and sought an explanation. Iraqi emerged out of his cell, placed his head at the Shaikh's feet and started weeping. The Shaikh raised his head from the ground, conferred his own robe on him and brought an end to his stay in the cell. The author of Siyar-ul-Arifin would have us believe that Iraqi wrote his book entitled Flashes (Lamaat) at the inspiration of Shaikh Bahauddin Zakariya. Written in the traditional form of poetry mixed with prose, it deals with several problems of mystic life in general and his own life in particular i.e., love revealed through the medium of human beauty. He believed that love was the only thing that existed in the world; the lover, beloved and love are one and, therefore, the question of union and separation was a thousand times better and more beautiful than the union desired by the lover; God was the eternally beautiful beloved, while the lover loved every order and action of the beloved; heart and love were one; love sometimes grew out of the heart like flowers; the whole world was nothing but an echo of lover's eternal song. In view of these ideas, it may be suggested that Iraqi transformed the mystical thoughts of Ibn-i-Arabi into a poetic form. We learn that Shaikh Bahauddin Zakariya had married his daughter to Iraqi. However, immediately after the death of the Shaikh (1262), Iraqi left Multan and reached Konya, where he met Sadruddinn Qunvi and perhaps Jalaluddin Rumi. Following his death in 1289, Iraqi was buried in Damascus near the grave of Ibn-i-Arabi. Annemarie Schimmel opines that Shaikh Bahauddin Zakariya would not have been so well known if the noted poet Iraqi had not lived in his entourage for nearly twenty five years. (Riazul Islam, 44)

Another creative intellectual associated with the mystical circle of Shaikh Bahauddin Zakariya was Sadruddin Ahmad bin Najmuddin Saiyyid Husaini, who was the reputed author of such works as Kanz-ul-Rumuz, Zad-Ul-Musafirin, Tarb-i-Majalis and Nuzhat-ul-Arwah. It was in response to he questions raised by Husaini that Mahmud Shabistari composed his masnavi 
entitled Gulshan-i-Raz. It is believed that Husaini completed his collection of poetry (diwan) Kanz-ul-Rumuz during his stay at the convent of Shaikh Bahauddin Zakariya. In this work, we come across poetic verses in the praise of Shaikh Bahauddin Zakariya and his son Shaikh Sadruddin Arif.

Sometimes the contemporary writings refer to ascetics called Qalandars and Jawaliqs who were known for their extremely unorthodox conduct. Though they were engaged in spiritual pursuits, yet they differed widely from the conventional sufis. They were opposed to the settled life of convents (khanqahs) and remained always on the move. They could be easily recognized owing to their outlandish appearance, particularly clothes and hair. But it was their impudent behavior which gave maximum offence to the mystics. Shaikh Bahauddin Zakariya, as a rule, did not permit the qalandars to enter his hospice. But sometimes he felt constrained to recognize their spiritual attainments. Once during the course of his travels, the Shaikh happened to be present at a congregation of the Jawaliqs. When he fixed his gaze on them, he saw light emanating from one of them. He saw light emanating from one of them. He went close to that person and asked" "What are you doing here in the company of these people. "He replied," Zakariya, so that you are informed that in each group of the commoners, there is one of distinction and excellence." However, this encounter did not reduce the Shaikh's aversion to them. Interestingly, this attitude was mutual. The Jawaliqs had doubts regarding the spiritual credentials of the Shaikh, probably because of his possession of wealth and the aristocratic character of his Khanqah. Once a group of Jawaliqs came to the khanqah of Shaikh Bahauddin Zakariya and demanded something. Since the Shaikh had a bad opinion about them, he refused to meet their demand. The Jawaliqs went out of the Khanqah, created an uproar and even threw brickbats at the door. The Shaikh had the door closed and declared that he had not settled there 
on his own and that the place had been selected as his abode by a man of God

(Shaikh Shihabuddin Suhrawardi). This statement had the desired effect. When the door was opened, the Jawaliqs prostrated themselves before the Shaikh and went away.

\section{Involvement in Politics}

Following in the footsteps of their masters in West Asia, the Indian Suhrawardis maintained close relations with the ruling class and did not hesitate to take part in contemporary politics. The following incident, as related by Shaikh Nizamuddin Auliya, assumes relevance in this context. We are aware of the conflict between Sultan Shamsuddin IItutmish (r.1210-1236) and Nasiruddin Qubacha, who held the territories of Multan and Uch. In these circumstances, two eminent citizens of Multan - Shaikh Bahauddin Zakariya and the judge (qazi) of the city sent letters to IItutmish, probably assuring their support. The letters fell into the hands of Qubacha, who was so incensed that he had the qazi killed and summoned the Shaikh to his court. The Shaikh went to the court and fearlessly sat on the right side of Qubacha as he used to do in the past. Qubacha handed over the shaikh's letter. The shaikh read the letter, confirmed that it was written by him and that it was in his own handwriting. Qubacha sought his explanation for having written such a letter. The shaikh declared that what he liked and that Quabacha could do nothing as he was powerless. Qubacha Still thought of punishing the Shaikh. He invited the Shaikh to join him for meals. He anticipated that the Shaikh would refuse, as he was very particular about not eating at any one's house and, in case of his refusal, he would get an excuse to do him some harm. However, the Shaikh joined others in eating the food. Qubacha's anger subsided and the Shaikh left for his lodge. $\quad$ (Dasti, 82). 
We can expect that the final defeat of Qubacha at the hands of IItutmish must have eased the situation for Shaikh Bahauddin Zakariya. Subsequently, the Shaikh developed cordial relations with the Sultan of Delhi. The remaining part of the Shaikh's life coincided with the reigns of the successors of IItutmish. However, we do not know the Shaikh's attitude towards them or towards the powerful governors of Multan - Kabir Khan Ayaz and Izzuddin Balban Kishlu Khan - Who administered the region as virtually independent rulers. The Shaikh appears to have kept aloof from the internal conflict within the ruling class, which often spilled over from Delhi to Multan. However, the Shaikh did intervene when Multan was threatened by the Mongols and the very life of its inhabitants was at stake.

During the early thirteenth century, the rise of the Mongols caused widespread devastation in central and western Asia. After the occupation of China and Transoxiana, Chengiz Khan overran the kingdom of Khwarizm and turned towards Afghanistan. Jalaluddin Mangbarni, the Khwarizmian prince, offered some resistance from Ghur and Ghazni before fleeing to India. When Jalaluddin mangbarni, the Khwarizmain prince, offered some resistance from Ghur and Ghazni before fleeing to India. When Jalaluddin Mangbarni entered Punjab in 1221, Nasiruddin Qubacha was ruling over Multan and Uch with the strong intention of occupying Lahore also; however, Qubacha position became vulnerable as he had to bear the brunt of mangbarni's hostil presence in central Punjab. In 1224, an army of 20,000 Mongols (two Invaded Multan and besieged the city. The people of Multan offered a stiff resistance to the invaders, who were forced to raise the siege and retreat. The compiler of the Fuwaid-ul-Fuad would have us believe that three sufis came to the rescue of Multan and employed their miraculous powers to save the city. It is related that once these three saints - Shaikh Bahauddin Zakariya, Shaikh Jalaluddin Tabrezi and Shaikh Qutbuddin Bakhtiyar Kaki-were together at 
Multan, which was then under the rule of Qubacha. An army of infidels (Mongols) attacked Multan and laid siege to the walled city. On one night, Shaikh Qutbuddin Bakthtiyar Kaki Gave an arrow to Qubacha and asked him to shoot it in the dark. This was done. Next morning, it was found that all the invaders had disappeared. The episode does hint at the unspecified role played by the three saints in ensuring the safety of the city from destruction at the hands of the Mongols.(Dasti, 83).

In 1246 a Mongol army led by Malik Shamsuddin and Sali Nuyin marched to Hindustan and laid siege to the city of Multan. At this time Chengiz Khan, a slave of Sultan Iltutmish was governor of Multan. After resisting the invaders for fourteen days, Chengiz Kah sent Shaikh Bahauddin Zakariya to the Mongal general Malik general Malik Shamsuddin, so as to persuade him to accept money and raise the siege. The Shaikh met Malik Shamsuddin who, in turn, carried the proposal to Sali Nuyin. It was agreed that Chengiz khan would pay a ransom of on lakh dinars and the invaders would retreat. Next day, the Shaikh delivered the said amount to Sali Nuyin and Chengiz Khan's presents for Malik Shamsuddin. In this manner, the active intervention of Shaikh Bahauddin Zakariya saved the inhabitants of Multan from death and destruction.

Emphasis on form

Shaikh Bahauddin Zakariya was extremely punctilious regarding the outward form of devotion. He did not tolerate even a minor deviation from what he regarded as the correct religious practice. He appears to have offended a number of people by his somewhat selfrighteous attitude, which was considerably similar to that of the orthodox theologians. Let us consider the following examples that were quoted by Shaikh Nuzamuddin Auliua during the 
course of his mystical discourses. According to one of these incidents, Shaikh Bahauddin Zakariya believed that a disciple must complete his ablutions or prayers before getting up to pay respects to his spiritual mentor. Once the Shaikh reached the bank of a river, where he found that a group of his disciples was engaged in performing the ablutions. As soon as they saw the Shaikh, they left their continued to perform the task till he had completed it and only then rose to pay his respects to his mentor. On observing the difference between the respective conducts of his disciples, the Shaikh declared that only one of them was a mystic (darvesh). This remark shows that in the eyes of the Shaikh the performance of a prescribe ritual was essential as well as meritorious. Even if a person dreamt that he had missed one of his regular prayers, he should feel penitent and take a vow of repentance for and abstinence from sins, because this opportunity could be denied owing to his death which could come any time (Humaira Arif Dasti, 89).

There was a man called Sulaiman who was known among the people of Multan for his devotional exercises. One day, Shaikh Bahauddin Zakarriya went to meet him. Apparently to check what he had heard from others. He asked Sulaiman to stand up and offer prayer of two rakaat. Contrary to the prescribed rule, Sulaiman did not keep the required space between his feet. The Shaikh advised him on the space between the feet, which could be neither more nor less than what was prescribed. However, Sulaiman failed to observe the rule of space between his feet, even though he tried a number of times. Thereupon, the Shaikh asked Sulaiman to leave Multan and to settle $\mathrm{n}$ Uch, which the man actually did.

Shaikh BahauddinZakariya walked everyday to the mosque attached to the seminary (madrasah) of Qazi Qutburddin Kashhani, who was known for his erudition and piety. Kashani asked the Shaikh the reason for his walking all the way to the place and offering his morning prayer behind someone else. The Shaikh replied that his conduct conformed to a prophetic 
tradition (hadis) according to which "One's praying behind a pious and lerned man was as if one had prayed behind a Prophet." One morning, the Shaikh arrived when the first rakaat had been completed his prayer before Kashani could turn to the right to say salam, denoting the completion of tashahhud. Kashani asked "Why did you stand up before the salam. The imam may have made a mistake which needed correction by performing the sajdah-i-sahw. Since you stood up before Salam, you may have missed it." The Shaikh replied that if one learnt through inner light that the Imam had not made any mistake by observing the obligatory details of prayer, one was allowed to rise. In response, Kashani observed that the light, which was not in harmony with the shariat, was nothing but darkness. Since the Shaikh was not prepared for this outcome of the encounter, he never came again to the place for prayer. (Humaira Arif Dasti, 89).

Shaikh Bahauddin Zakariya was strict not only about religious obligations and the manner of their observance, but he also paid equal attention to one's dress and hair. In case, he found anyone in improper dress or wearing his hair in an unacceptable manner, he did not hesitate to issue a sharp reprimand. Once a learned scholar (danishmand) arrived from Bukhara to Multan and came to pay his respects to Shaikh Bahauddin Zakariya. The Shaikh was angered on seeing the visitor, as he had curled hair (mujaad) and the end of his turban was hanging loose. The Shaikh asked the visitor the purpose of arriving with two snakes, i.e., curled hair and loose end of the turban. The visitor was so upset by the remark that he immediately got his head shaved in the very presence of the Shaikh. It appears that people belonging to the mystic circle of the Shaikh had also adopted the same attitude. A group of the Shaikh's companions, while on a visit to the khanqah of Shaikh Nizamuddin Auliya at Delhi, walked out of meals on seeing a guest supporting curled hair (mujaad). 


\section{Assessment and Legacy}

Shaikh Bahauddin Zakariya and his successors have been criticized on several groundsaccumulation of wealth, elitist character of the Suhrawardi khanqah, participation in politics and limited expansion in non-Muslim environment-which were connected with one another. Most often, a small incident is quoted on the authority of Fuwaid-ul-Fuad and which has been repeated in Siyar-ul-Auliya. It is related that the governor of Multan, on one occasion, borrowed some grain from Shaikh Bahauddin Zakariya. When this grain was being removed from his granaries, pitchers of silver tankahs were found concealed therein. The abundance of wealth excited the cupidity of robbers, who resorted to blackmail in order to extract money from the Shaikh's sons. It is also alleged that the Shaikh paid huge sums of money to the tutors of his sons. Our attention is drawn to the lavish and aristocratic organization of the Suhrawardi khanqah at Multan. It was not open to the common people and it was run on the principles of social hierarchy which appeared incompatible with the substance of mysticism. In fact, Suhrawardi accumulation of wealth had generated an acrimonious debate within the larger mystic circle of north -western India. Jalaluddin Tabrazi (a Suhrawardi) and Hamiduddin Nagauri Suwali carried a correspondence on this issue. In the words of Nizami," The replies given by the Suhrawardi saints were more rhetorical than logical and the quick witted questioners refused to be confused by rhetoric and platitudes." In an attempt to explain the limited appeal of the Suhrawardis, it has been argued that they (in contrast to the Chishtis) emphasized the necessity of regulating actions prior to the control of emotions. This dampened the prospects of Suhrawardi expansion in a non-Muslim environment. It worked well in Muslim surroundings and served the spiritual needs of the Muslim community but when it came to non-Muslim lands its progress stopped. On the question of religious conversion, the Suhrawardi 
attitude of sectarianism is highlighted along with the Chishti stance of communal harmony.(Nizami, 240).

Qazi javed is strongly critical of the association of Suhrawardis with the contemporary rulers. In his eyes, the support of Shaikh Bahauddin Zakariya for IItutmish was decisive in shaping the future development of the Suhrawardi order. Having come under the regional influence, it lost its independence and became a puppet in the hands of the rulers. The outlook of the Suhrawardis gradually became similar to that of the courtly theologians and nobles, so that Ruknuddin Abul Fateh and Syed Jalaluddin Bukhari began to advocate unconditional subordination to the rulers. In justification of their stance, they argued that it helped in creating an Islamic atmosphere in the royal court. The merger of mysticism and politics of mutual accommodation caused great harm to the former. In fact this had surfaced in the times of Shaikh Bahauddin Zakariya. (Riazul Islam, 50).

It is not possible for us to agree with the above understanding on account of several factors. It is not only harsh and one-sided, but also fails to pay adequate attention to the socio-political context in which Shaikh Bahauddin Zakariya lived. Firstly, we are bound to keep in mind the mystical inheritance of the Indian Suhrawardis. They had imbibed the teaching of the famous Suhrawardi masters of West Asia, particularly Abu Najib Abdul Qahir and Shaikh Shihabuddin Suhrawardi. These saints, having been inspired by the mystical ideology of Shaikh Junaid Baghdadi, had clearly rejected the ideas of intoxication (sukr) and stressed the Islamic law (shariat) as the foundation of spiritual development. On the one hand, they recognized the significance of the outward form of devotion, and on the other, they brought with them a fully developed system of thought and planted it successfully in the new environment. They could not be situations; they displayed their loyalty and commitment to the mystical 
principles of their order, though they might have been required to make some minor compromises .(Humaira Arif Dasti, 89)

Secondly, the Multan region was passing through a critical phase during the first half of the thirteenth century. The Delhi sultanate had not consolidated as a systematic political structure, because there were perpetual factional conflicts within the ruling class. The political condition was further complicated by the intrusion of foreign invaders - Mongols, Khwarizmians and Qarlughs - who succeeded in establishing their sway in different parts of Punjab and threatened to annex Multan also. The successive governors of Multan, Kabir Khan Ayaz and Izzuddin Balban Kishlu Khan, thought it prudent to rule independently of Delhi, formally or informally. The Mongols had extended their influence up to the Beas, while the Delhi sultanate displayed its inability to recover the lost territories. The Mongols, who were notorious for their destruction and fruelty, and struck terror in all directions. The common people were the worst sufferers of internal instability and foreign invasions. Since their socio-economic life was frequently disrupted, they found it difficult to protect their homes and hearths.(Niazi, 260)

Nobody was more conscious of the gravity of the situation than Shaikh Bahauddin Zakariya. Since he was born and brought up in Multan, he was aware of the socio-economic conditions of the people as well as their religious beliefs and practices. During his long stay in West Asia, he must have observed the emergence of mystic orders and political disintegration of the caliphate, besides the challenge posed by the Mongol irruption. When he established the Suhrawardi order in Multan during the first quarter of the thirteenth century, he found this region in fact, continued till the very end of his life (1265). This extraordinary situation could be mitigated only be extraordinary measures. This provides a clue to the Shaikh's political involvement and accumulation of wealth. He sought to achieve these aims by forging an intimate 
alliance with the ruling class, which brought in exalted titles, valuable gifts and land grants. His initiative appears to have led to the promotion of trade which, despite the constant threat of foreign invasions, was the only source of survival and prosperity of the people of Multan. Besides being a centre of mystic discipline, his khanqah also served as a centre of education, as the seminary (madrasah) attached to it provided instructions in exegesis (tafsir), Prophetic traditions (hadis) and Muslim Jurisprudence (fiqh). The Khanqah became a meeting ground of mystics, scholars, nobles, merchants, musicians and commoners. The presence of such eminent poets as Fakhruddin Iraqi and Sadruddin Ahmad bin Najmuddin Saiyyid Husaini indicates that the literary atmosphere of the khanqah attracted creative minds from distant lands. (Humaira Arif Dasti, 90). As a rule, discussion of theological matters was avoided. Emphasis was laid on the discipline of inner life and emotional integration in the light of religious teachings, rather than intellectual advancement through casuistry.

Humaira Arif Dasti states, "In contrast to the Chishtis who stood for starvation and self-mortification, Shaikh Bahauddin Zakariya advocated a normal and balanced life which accorded equal care to the body and spirit. By negating the ascetic and passive tendencies in Islamic mysticisms, he introduced a contrastive model of human development which was designed to resolve political, social and spiritual problems of the society. This dispensation was based on a judicious merger between the Islamic law (shariat) and Islamic spirituality (tariqat). He believed in the continuity $\mathrm{f}$ the religious structure of Islam and maintaining the purity of its outward from. But he did not hesitate to mould the mystical dimension of Islam to suit the dire socio-political needs of the locality. He performed this difficult task by weaving the different threads of spiritual thought into a holistic pattern which, though contrastive in relation to parallet systems, manifested itself in an aesthetic image. It was on account of these factors that the 
Shaikh's mystical approach was adopted by a large number of people of Multan. The success of the Shaikh's mission was reflected in his rich legacy as well as the consolidation and expansion of the Suhrawardi order under his able successors. It is true that his immediate successor Shaikh Safruddin Arif (d.1285) discarded a few fundamental principles of his predecessor. However, the subsequent Suhrawardi examplers reverted to the mystical school of Shaikh Bahauddin Zakariya. Shaikh Ruknuddin Abul Fateh, who served for nearly half a century (1285-1335) as the spiritual head of the Suhrawardi order in Multan, carried the discipline to the greatest heights of popularity. Syed Jaluddin Surkh bukhari, a disciple of Shaikh Bahauddin Zakariya, founded a branch of the order in the neighboring town of Uch. It was under the stewardship of his charismatic grandson, Syed Jalaluddin Bukhari Makhdum-i-Jahaniyan, that the Uch branch played a significant role in the socio-political life of north-western India. Thus we see that the mystical doctrines and practices of Shaikh Bahauddin Zakariya can be better appreciated if they are viewed in their specific context and assessed in terms of their long term consequences." (94) 
Bibliography

Dasti, Humaira Arif, "Path of Shaikh Bahauddin Zakariya: A Contrastive Model of Mysticism" Sufism in Punjab, Mystics, Literatures and Shrines (ed Surinder Singh, Ishwar Dayal Gaur), New Delhi, Aakar Books, 2009.

Nizami, Khaliq Ahmad, On History and Historians of Medieval India, New Delhi, Munshiram Manoharlal, 1983.

Nizami, Khaliq Ahmad, Some Aspects of Religion and Politics in India during the Thirteenth Century, Delhi, Idarah i Adabiyat i Delhi, 1974/

Rizvi, Saiyid Athar, A History of Sufism in India, Vol 1, New Delhi, Munshiram Manoharlal, 1978.

Sijzi, Amir Hassan, Fawaid ul Faud.

Subramony, R, Sufi Mystics of Punjab, New Delhi, Academic Books International, 2018 